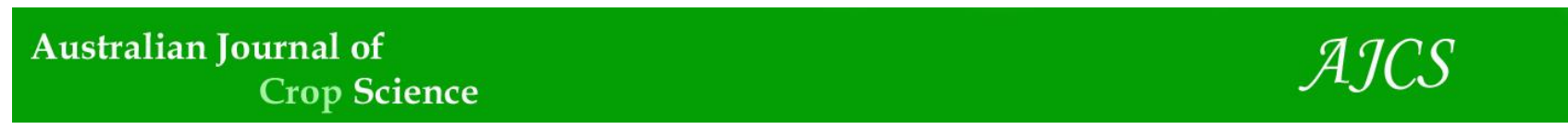

AJCS 12(08):1297-1303 (2018)

ISSN:1835-2707

doi: 10.21475/ajcs.18.12.08.PNE1095

\title{
Application of geostatistics tools to evaluate droplets spectrum of a common spray atomizer using several additives
}

\author{
Sanchez de C. Lacerda, Elton F. dos Reis, Luana de L. Lopes, Sueli M. F. Alves \\ Universidade Estadual de Goiás, Campus Anápolis de Ciências Exatas e Tecnológicas - Henrique Santillo, BR 153, ${ }^{\circ}$ \\ 3.105, Fazenda Barreiro do Meio, CEP 75132-903, Anápolis, GO, Brasil. Caixa Postal 459
}

*Corresponding author: luanalopes100@yahoo.com.br

\begin{abstract}
The objective of this work was to evaluate the spectrum of droplets and syrup deposition of motorized costal atomizer, using additives in spraying solution. For this purpose geostatistical approach was applied. The treatments such as water (witness) and different additives (mineral oil, siliconized polymer and ethoxylated nonylphenol) were applied. Just before application, collectors (glass plates and hydrosensitive labels) were distributed at seven distances from the center of the spray circumference with different radius $(3.0,6.0,9.0,12.0,15.0,18.0$ and $20.0 \mathrm{~m})$, in the directions of the cardinal and collateral points, totaling 56 sample points. The deposition parameters, volumetric median diameter (VMD), relative amplitude (RA) and coverage were evaluated by means of aqueous solution (spray liquids + dye) to verify deposition by spectrophotometry and hydrosensitive paper label for the spectrum of drops. Descriptive analysis of the data was performed and geostatistics used as a tool for the analysis of spatial variability. The values for non-sampled locations were estimated using the ordinary kriging interpolation method. It allowed mapping that defined the application zones for the calculation of drift. The results showed that the VMD of the droplets was 136 $\mu \mathrm{m}$. The application maps showed that there was a drift of $71.50 \%$ of the volume of syrup applied. The geostatistical tool made it possible to evaluate the droplet and deposition spectrum by means of the application maps. The proposed climatic recommendations for the application of agricultural pesticides do not apply to cost atomizers.
\end{abstract}

Keywords: additives; air assistance; deposition; drift; application technology.

Abbreviations: RA_Relative Amplitude, VMD_Volumetric Median Diameter, ISD_Index of Spatial Dependence.

\section{Introduction}

Spraying technology of formulations (such as insecticides, fungicides, etc.) is mainly based on the most efficient and safe mix pulverization, using the lowest volume of calcium available to obtain the highest coverage with the lower drift loss and human contamination (Baetens et al., 2009). Spryaing under climatic conditions with relative reduction to $50 \%$ and a wet bulb temperature above $30{ }^{\circ} \mathrm{C}$ stimulate early evaporation of spray droplets. The wind velocity above $3 \mathrm{~m}$ $\mathrm{s}^{-1}$ can blow away lighter droplets characterizing a spray derivate (Minguela e Cunha, 2010; Boller et al., 2011). Additives are compounds that are usually added to formulations or to the spray mixtures to improve wetting, adherence, non-spreading, foaming reduction and dispersion of spray mixtures (Cunha et al., 2010). However, according to Antuniassi et al. (2008), misuse of additives may lead to unknown negative effects, including non-expected effects or drift decrease on pulverization agriculture. The use of the pneumatic costal spray (sprayer) in cultures with high leaf density has been commonly approved since the air flow produced by the internal combustion engine promotes the movement of the leaves of the plants, facilitating the penetration of the drops into the canopy. Unlike hydraulic sprayers, the assistance of air over the formed droplets allows a greater spray jet range, allowing more homogeneous applications (Paixão, 2016). The study of spatial variability through geostatistics allows interpretation of the results based on the structure and natural variability of the evaluated attributes. The spatial dependence within the sampling interval (Souza et al., 2009) is an alternative, allowing a better understand of variability of the attributes and their influence on the environment (Silva Neto et al., 2012). Cokriging is a geostatistical procedure, according to which several regionalized variables can be estimated together based on the spatial correlations. It is a multivariate extension of the kriging method, when in each sampled location a vector of values is obtained instead of a single value (Angelico, 2006). The intercorrelation between variables is called coregionalization, which describes the spatial correlation between the variables in different locations. This correlation may be positive or negative, and the negative value indicates inverse correlation (Duarte, 2015). In this way, this work has the objective of evaluating the droplet spectrum and deposition of motorized costal atomizer spray using adjuvants in the pulverization applying the geostatistical method. 


\section{Results and Discussion}

\section{Descriptive analysis of the studied variables}

There was no normal distribution of data for all the studied variables. The descriptive analysis (Table 1 ) showed the presence of high coefficients of variation for deposition, between 146.15 and $252.46 \%$. Analyzing kurtosis, addition of silicone polymer, vegetable oil and nonylphenol ethoxylate obtained 5.14, 13.42 and 12.97 of spray mix deposition, respectively, demonstrating high data elevation compared to normal curve, characterizing spray mix deposition contrast within study area. For water and additives deposition variables, there were high skewness index, according to Figueiredo et al. (2009) and Pearson coefficient. Kriging does not require normality and low skewness of the data. However, kriging is better executed with data, which present normality due to semivariogram adjustment and facilitate kriging process (Machado et al., 2007). Descriptive analyses of VMD, RA and air coverage were the only positive deposition points. VMD for different types of additives showed values between 128 and $143 \mu \mathrm{m}$; thus, classified as fine droplets, according to Doble et al. (1985); and relative amplitude between 0.81 and 0.92 . Rodrigues (2005) found that VMD can vary between 187 and $476 \mu \mathrm{m}$ in hydropneumatic sprayers with JA-2 nozzles, depending on ventilator air speed. However, Reis et al. (2010) studied spray mix deposition using rotative atomizers on air plane and VMD was $144.5 \mu \mathrm{m}$ and relative amplitude was lower than 1.0 for the upper canopy of the plants, values close to those found in this study.

\section{Maps of studied spray variables}

Table 2 shows the best results fitted to experimental semivariances for droplets characteristics and deposition. When deposition maps created from a theoretical model and ordinary kriging are analyzed (Fig. 1), predominance of deposition spray mix is noticed in northwest direction. Even according to climatic recommendations for application of pesticides, spray droplets transportation was affected by the wind. The use of air handling equipment to propel spray droplets are more sensitive to wind speed variation and recommendations for application of pesticides are not suitable for use, suggesting more studies to determinate the best use for these equipments. Jamar et al. (2010) studied deposition of different nozzles in hydropneumatic sprayer at orchards. Deposition on wind direction was significant between droplet size and wind speed in horizontal displacement (drift) of agriculture pulverization. Spatial variability can analyze open-air droplets spectrum characteristics as droplet size and application form, speed of electric energy production and pesticides expectation of deposition using terrestrial atomizers. Analyzing variability maps of VMD, RA and coverage (Fig. 2, 3 and 4), deposition of droplets bigger than $100 \mu \mathrm{m}$ is concentrated on the first $10 \mathrm{~m}$ far from the equipment and coverage as well. Meanwhile, VMD lower than $100 \mu \mathrm{m}$ is related to the most distant location from pulverization center, proving droplets susceptibility to wind transportation. Higher values on the relative amplitude maps (Fig. 4) are related to higher VMD and coverage, these regions represent nominal deposition of the equipment. Regions further than $10 \mathrm{~m}$ from the pulverization center have low values of VMD and RA. Deposition on this location consisted of droplets predominantly shorter than $100 \mu \mathrm{m}$. According to Cunha et al. (2010), these droplets are too thin and have high drift potential. Hydrosensitive paper labels located at $20 \mathrm{~m}$, responsible to indicate drift direction out of study area showed that there was spray drift to northwest and west in all used adjuvants. Analyzing droplet spectrum on hydrosensitive paper labels at $20 \mathrm{~m}$ points, mean VMD and

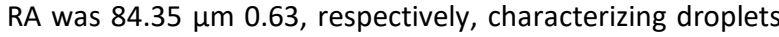
of high potential drift and difficult control. For a better sizing of pesticides droplets, it is essential to know that extra quantity of deposited spray may mix with wind, reducing application time per area; therefore, maximizing operational capacity of the equipment. Change in direction of spray droplets was southwest to northwest on the same way as equipment. In this situation, the applier receives deposition. Several authors reported the lack of individual protection equipment (IPE) and correct use of appliers, as well as environmental and human contamination index coming from pesticides drift explosion (Cunha, 2008; Gebler, 2011; Quirino et al., 2013). Therefore, besides the drift loss factor it is important to avoid application of pesticides against the wind as much as possible. This will reduce the exposure of the applicator to the pesticide used. Total mean deposition was calculated by sum of each distance mean at their respective influence area. It was $1.140 \mathrm{~L}$ of deposition on study area, which was $71.5 \%$ of volume of spray mix applied $(4.0 \mathrm{~L})$. At $18-20$ meters distance, there was $1.8 \%$ of drift deposition on the soil. The hydrosensitive paper located at twenty meters points, indicated drift towards north and northwest. Cunha (2008) studied different droplets sizes and horizontal speeds and found that horizontal distance travelled is affected by droplets release height. Several authors reported drift difficulties using equipments that produce small droplets, mainly in unfavourable weather conditions (Balan et al., 2008, Cunha et al., 2010, Boller et al., 2011, Rodrigues et al., 2012, Quirino et al,. 2013). High initial speed utilized by equipment to spray propulsion and low pulverized droplets (VMD) promoted acceleration of the evaporation, maximizing the drift and reducing life time during the application.

\section{Correlation}

For all additives there was a strong correlation between deposition and coverage, as shown on Table 3. According to Fritz et al. (2012), droplets size is a decisive factor related to deposition both inside and outside of the target. Fine droplets can increase spray coverage, consequently, the products efficiency (Derksen et al., 2007). However, Schneider et al. (2013) claimed that droplets evaporation must be disregarded; because once droplets evaporated they will not be deposited on the target. Volumetric Median Diameter (VMD) and correlation index ( $r$ ) of water reduced compared to Nonylphenol ethoxylate. The results corroborate with Scheneider et al. (2013). Correlation decrease can be related to interference of random factors inserted by wrong adjuvant dosage for atomizer application (Antuanissi et al., 2008; Durigen et al., 2008). 
Table 1. Descriptive analysis of spray mix deposition data, VMD (Volumetric Median Diameter), RA (relative amplitude) and coverage for water, and additives silicone polymer, vegetable oil and ethoxylated nonylphenol.

\begin{tabular}{|c|c|c|c|c|c|c|c|c|}
\hline Variable & $M$ & SD & SV & Min & Max & Kurt. & $A C$ & VC \% \\
\hline \multicolumn{9}{|l|}{ Deposition* } \\
\hline Water & 0.26 & 0.38 & 0.142 & 0 & 1.44 & 1.40 & 1.53 & 146.15 \\
\hline Silicone polymer & 0.20 & 0.49 & 0.236 & 0 & 1.88 & 5.14 & 2.56 & 245.00 \\
\hline Vegetable oil & 0.71 & 1.75 & 3.058 & 0 & 10.04 & 13.42 & 3.41 & 246.48 \\
\hline Ethoxylated nonylphenol & 0.61 & 1.54 & 2.363 & 0 & 8.69 & 12.97 & 3.42 & 252.46 \\
\hline \multicolumn{9}{|l|}{ VMD } \\
\hline Water & 143.07 & 43.26 & 1871.82 & 84.42 & 243.18 & 0.18 & 0.68 & 30.24 \\
\hline Silicone polymer & 141.84 & 40.01 & 1600.85 & 73.55 & 204.62 & -1.05 & -0.27 & 28.20 \\
\hline Vegetable oil & 135.96 & 38.58 & 1488.47 & 79.32 & 237.35 & 1.08 & 0.82 & 28.38 \\
\hline Ethoxylated nonylphenol & 127.94 & 35.84 & 1284.53 & 81.35 & 204.37 & -0.75 & 0.48 & 28.01 \\
\hline \multicolumn{9}{|l|}{ RA } \\
\hline Water & 0.92 & 0.17 & 0.028 & 0.66 & 1.21 & -1.13 & 0.28 & 18.48 \\
\hline Silicone polymer & 0.81 & 0.23 & 0.054 & 0.43 & 1.20 & -0.81 & -0.07 & 28.87 \\
\hline Vegetable oil & 0.89 & 0.27 & 0.075 & 0.44 & 1.57 & 0.74 & 0.46 & 30.50 \\
\hline Ethoxylated nonylphenol & 0.82 & 0.16 & 0.026 & 0.53 & 1.05 & -1.18 & -0.20 & 19.78 \\
\hline \multicolumn{9}{|l|}{ Coverage } \\
\hline Water & 12.79 & 7.87 & 61.87 & 0.30 & 23.3 & -1.43 & 0.01 & 61.53 \\
\hline Silicone polymer & 12.62 & 8.20 & 67.29 & 0.30 & 23.80 & -1.49 & -0.17 & 65.00 \\
\hline Vegetable oil & 13.84 & 8.66 & 74.99 & 0.10 & 24.30 & -1.43 & -0.54 & 67.44 \\
\hline Ethoxylated nonylphenol & 10.33 & 7.81 & 61.00 & 0.30 & 23.50 & -1.42 & 0.34 & 75.58 \\
\hline
\end{tabular}

Table 2. Theoretical models of semivariance adjusted for deposition and characteristics of the droplet spectrum and spray for water and the different types of formulation of agricultural adjuvants.

\begin{tabular}{|c|c|c|c|c|c|c|c|}
\hline Variable & Model & $\begin{array}{l}\text { Nugget Effect } \\
\text { (Co) }\end{array}$ & Sill $(\mathrm{Co}+\mathrm{C})$ & Range* (Ro) & $\mathrm{R}^{2}$ & $\operatorname{ISD}(\mathrm{Co} /(\mathrm{Co}+\mathrm{C}))$ & Residue \\
\hline \multicolumn{8}{|l|}{ Deposition** } \\
\hline Water & Gaus. & 0.0001 & 0.172 & 5.86 & 0.887 & 0.999 & 0.0044 \\
\hline Silicone polymer & Gaus. & 0.0001 & 0.283 & 4.44 & 0.716 & 1 & 0.0339 \\
\hline Vegetable oil & Gaus. & 0.01 & 3.706 & 3.49 & 0.529 & 0.997 & 9.44 \\
\hline $\begin{array}{l}\text { Ethoxylated } \\
\text { nonylphenol }\end{array}$ & Gaus. & 0.001 & 2.877 & 4.28 & 0.721 & 1 & 3.37 \\
\hline \multicolumn{8}{|l|}{ VMD } \\
\hline Water & Gaus. & 10 & 5080 & 4.58 & 0.823 & 0.998 & 5176207 \\
\hline Silicone polymer & Gaus. & 10 & 5178 & 5.44 & 0.937 & 0.998 & 2110788 \\
\hline Vegetable oil & Gaus. & 10 & 4971 & 5.28 & 0.877 & 0.998 & 3390481 \\
\hline $\begin{array}{l}\text { Ethoxylated } \\
\text { nonylphenol }\end{array}$ & Gaus. & 10 & 4826 & 5.94 & 0.874 & 0.998 & 3176534 \\
\hline \multicolumn{8}{|l|}{ RA } \\
\hline Water & Gaus. & 0.0001 & 0.201 & 6.65 & 0.951 & 1 & 0.00251 \\
\hline Silicone polymer & Gaus. & 0.0001 & 0.170 & 6.72 & 0.956 & 0.999 & 0.0017 \\
\hline Vegetable oil & Gaus. & 0.0001 & 0.218 & 5.58 & 0.887 & 0.998 & 0.00662 \\
\hline $\begin{array}{l}\text { Ethoxylated } \\
\text { nonylphenol }\end{array}$ & Gaus. & 0.004 & 0.190 & 6.80 & 0.880 & 0.979 & 0.00484 \\
\hline \multicolumn{8}{|l|}{ Coverage } \\
\hline Water & Gaus. & 0.1 & 54.160 & 4.95 & 0.811 & 0.998 & 747 \\
\hline Silicone polymer & Gaus. & 0.1 & 57.510 & 5.81 & 0.916 & 0.998 & 399 \\
\hline Vegetable oil & Gaus. & 0.1 & 70.430 & 5.60 & 0.898 & 0.999 & 606 \\
\hline $\begin{array}{l}\text { Ethoxylated } \\
\text { nonylphenol }\end{array}$ & Gaus. & 0.1 & 51.240 & 4.84 & 0.791 & 0.998 & 761 \\
\hline
\end{tabular}




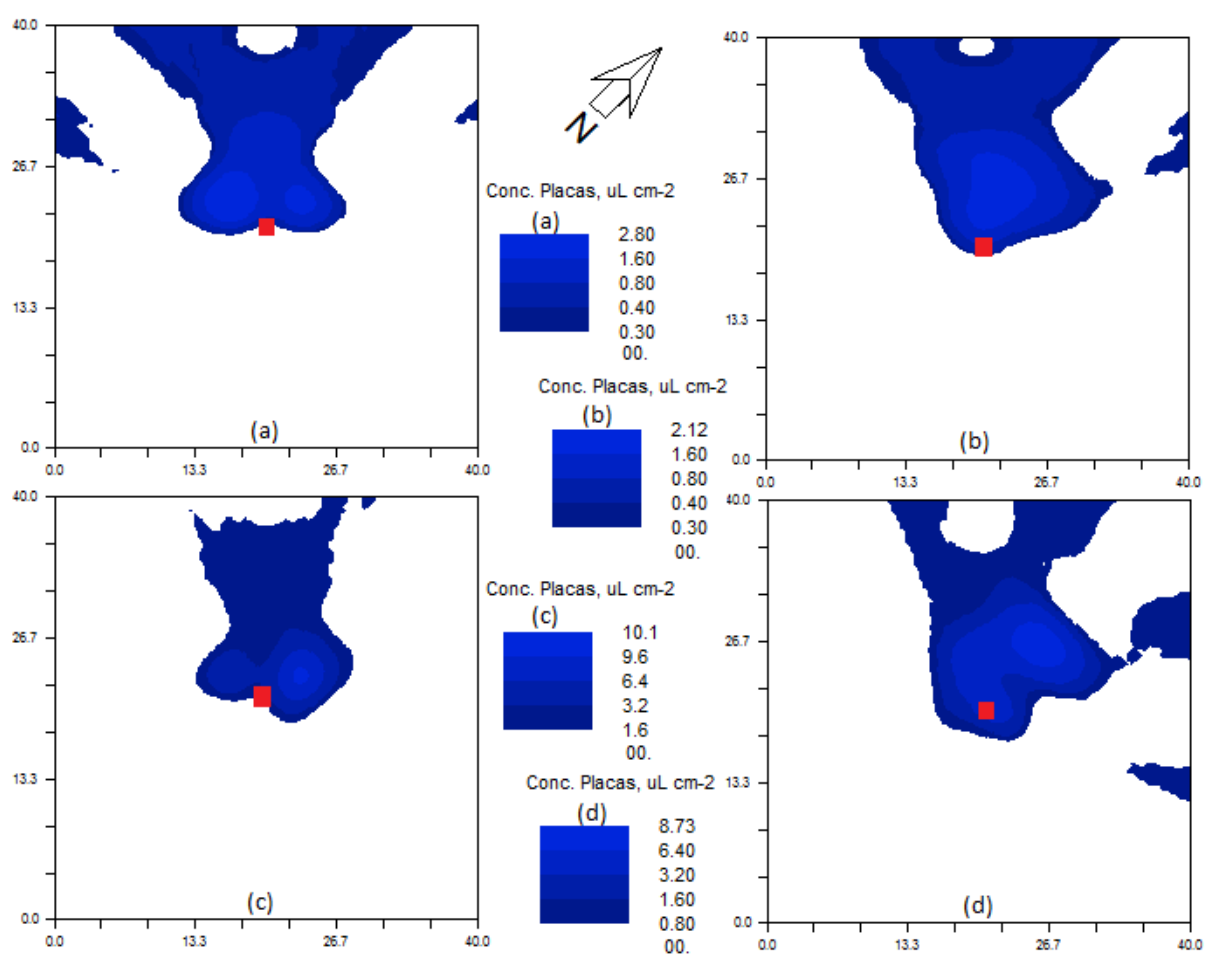

Fig 1. Map of spray mixture deposition using backpack atomizer. (a) water, (b) siliconized polymer, (c) mineral oil and (d) nonylphenol ethoxylate, for application of spray mix volume of $0.4 \mu \mathrm{L} \mathrm{cm}$. Darker blue tones are the lowest deposition values and the red dot shows the location of the sprayer.
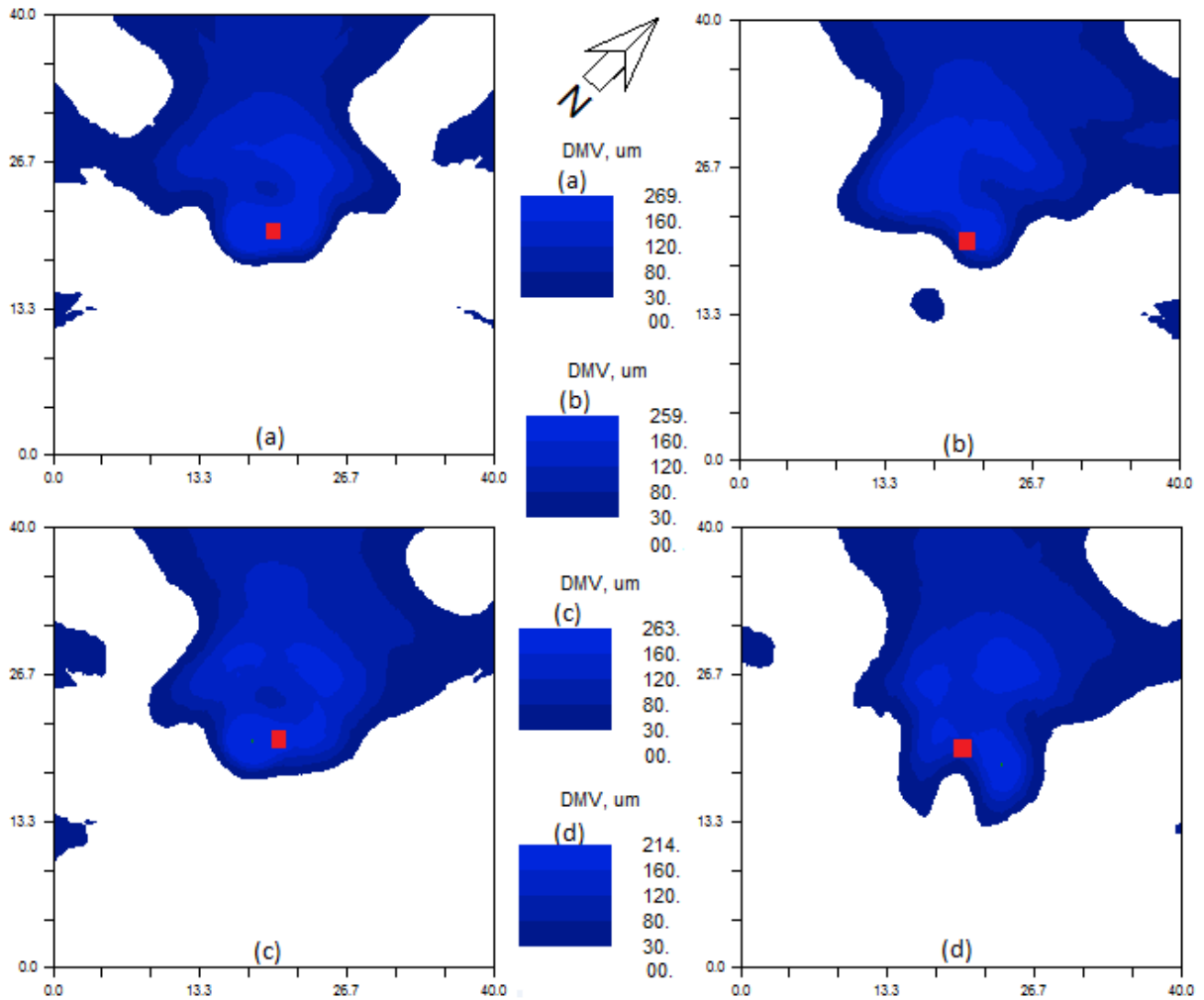

Fig 2. Map of spacial variability for VMD using backpack atomizer. (a) water, (b) silicone polymer, (c) mineral oil and (d) nonylphenol ethoxylated, for spray mix volume application of $0.4 \mu \mathrm{L} . \mathrm{cm}^{-2}$. Darker blue tones are the lowest deposition values and the red dot shows the location of the sprayer. 
Table 3. Interpretation of Pearson correlation index to spray mix deposition data and coverage.

\begin{tabular}{lll}
\hline Additive & $\begin{array}{l}\text { Correlation index to } \\
\text { deposition and coverage }(r)\end{array}$ & Interpretation \\
\hline Water & 0.9222 & High correlation \\
Silicone polymer & 0.9205 & High correlation \\
Vegetable oil & 0.8534 & High correlation \\
Ethoxylated nonylphenol & 0.8410 & High correlation \\
\hline
\end{tabular}
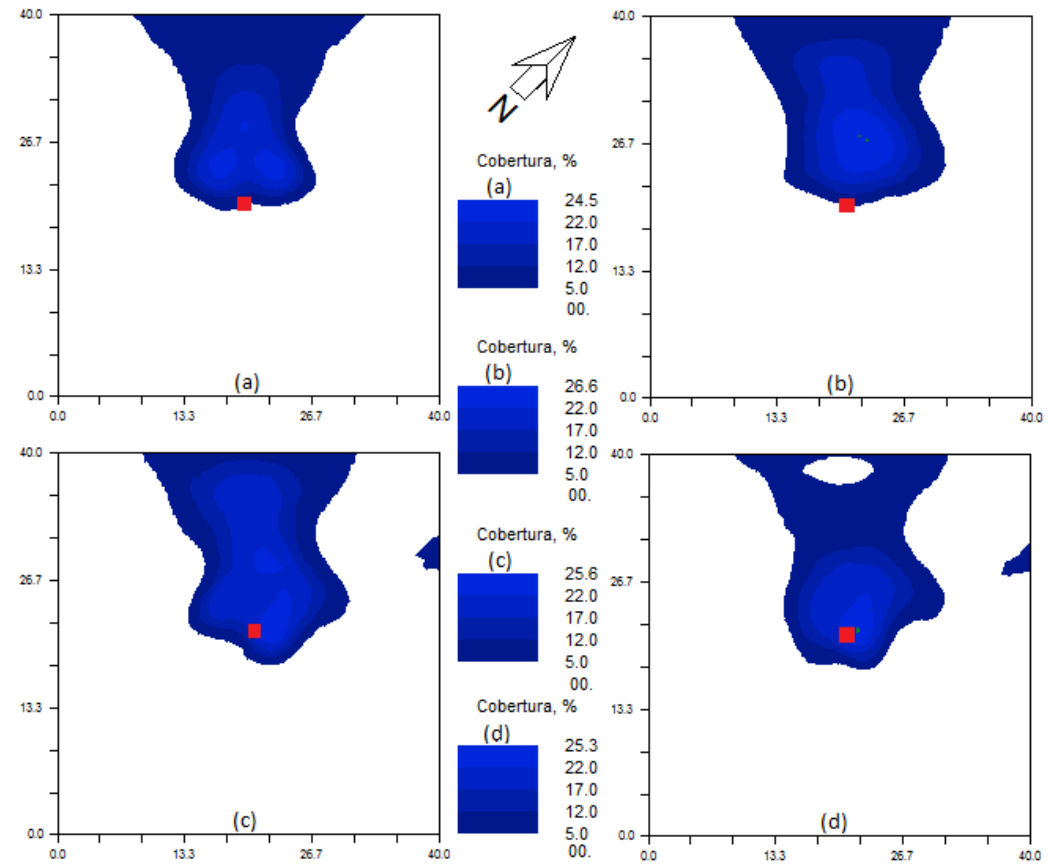

Fig 3. Map of spatial variability coverage using backpack atomizer. (a) water, (b) siliconized polymer, (c) mineral oil and (d) nonylphenol ethoxylate, for application of spray mix volume of $0.4 \mu \mathrm{L} \mathrm{cm}$. Darker blue tones are the lowest deposition values and the red dot shows the location of the sprayer.
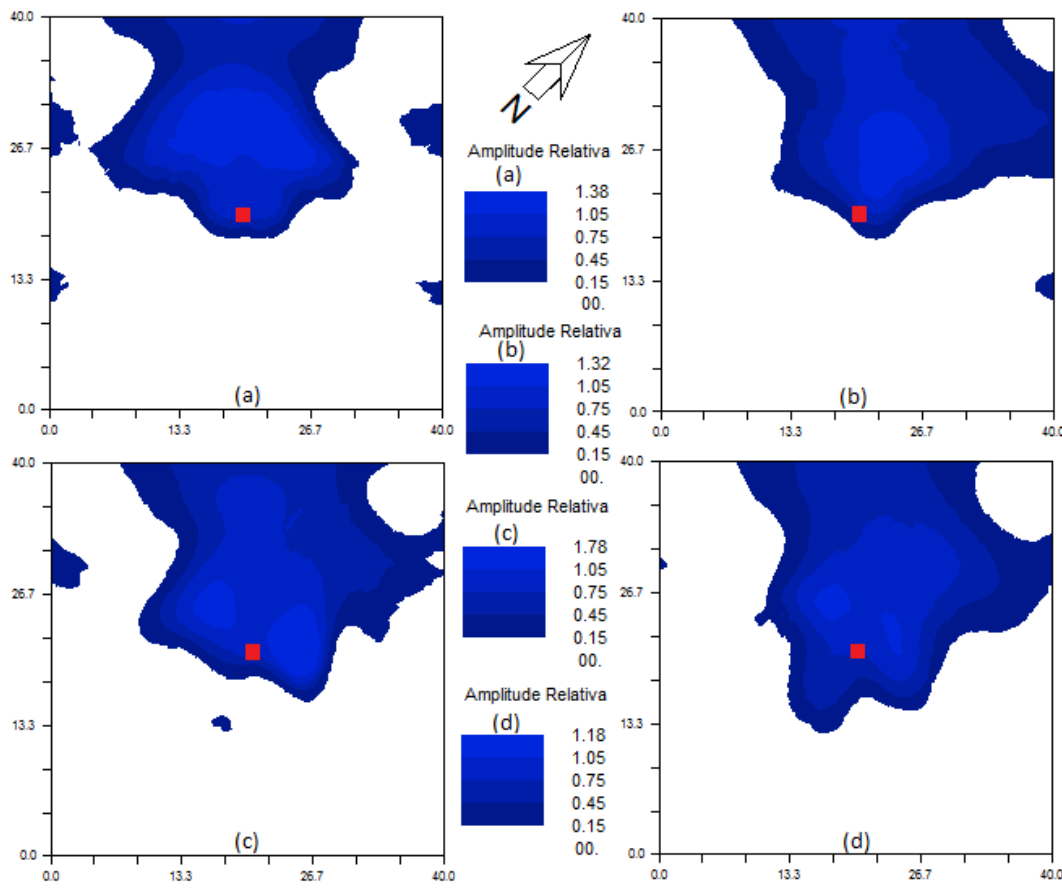

Fig 4. Spacial variability map for relative amplitude (RA) using backpack atomizer. (a) water, (b) siliconized polymer, (c) mineral oil and (d) nonylphenol ethoxylate, for application of spray mix volume of $0.4 \mu \mathrm{L} \mathrm{cm}{ }^{-2}$. Darker blue tones are the lowest deposition values and the red dot shows the location of the sprayer. 


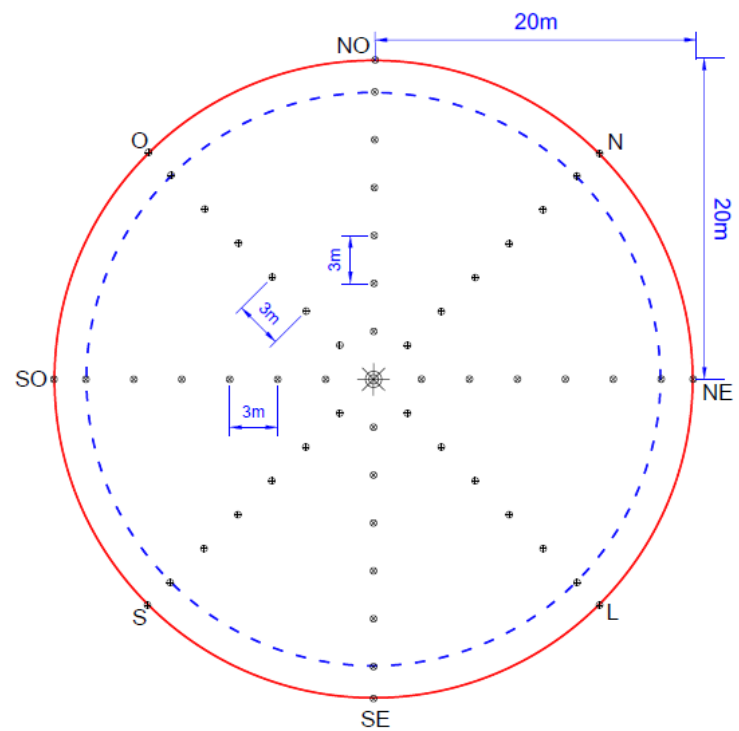

Fig 5. Drift collectors distribution on study area in platform rotating, spaced 3 meters each towards cardinal and collateral points. Where; $\mathrm{NO}=$ northwest; $\mathrm{N}=$ north; $\mathrm{NE}=$ northeast; $\mathrm{L}=$ east; $\mathrm{SE}=$ southeast; $\mathrm{S}=$ south; $\mathrm{SO}=$ south-west; $\mathrm{O}=$ west.

\section{Materials and methods}

\section{General information}

Study area comprised of a circle with 20 meters radius (Fig 5) without vegetation and maximum spray range of atomizer was considered 18 meters, as described in the manufacturer's manual, taken as expected deposition in the circle radius. A motored atomized backpack with $18 \mathrm{~L}$ of capacity, ACM 18L-AT75 model with $3.48 \mathrm{KW}$ sprayer motor, model TK065D - AT75E, single-cylinder with two strokes to pulverization was used. The sprayer's nozzle had flow of 1.33 $\mathrm{L} \mathrm{min}^{-1}$ and stirrer in position 2 (maximum).

\section{Implementation and conduction of study}

The atomizer was fixed on a rotating platform, 0.60 meters from the ground. The spray's nozzle was fixed at 1 meter from the ground in $45^{\circ}$ angle. The platform was powered by a motor and controlled by a frequency inverter, with angular velocity of $0.011 \mathrm{rad} \mathrm{s}^{-1}$, resulting in application of 4 liters of spray mixture on the area. Sampling grid was established in 8 directions, spaced in 3 meters in each direction until $18 \mathrm{~m}$ and an extra collector in $20 \mathrm{~m}$ with atomizer in the center, as shown in Fig. 5, totally 56 sampling points. In each point deposition was collected using collector plaques and droplets spectrum utilizing hydrosensitive labels. Temperature, relative humidity, wind velocity and direction were monitored randomly. Experiments were performed at 6:45 a.m. and temperature varied from 16.5 to $22.8{ }^{\circ} \mathrm{C}$; relative humidity, 62 to $72 \%$; wind velocity, 1.00 to $1.35 \mathrm{~m} \mathrm{~s}^{-}$ 1 , and wind direction was predominantly to northwest. Formulations for the additives were made with commercial products BreakThru ${ }^{\circledR}$ (Silicone Polymer - 100\%), Assist ${ }^{\circledR}$ (Mineral Oil - 75.6\%) and Haiten ${ }^{\circledR}$ (Nonylphenol ethoxylate $20 \%$ ), using recommended doses of the manufacturer for application. In every collection point a hydrosensitive paper label was fixed (Wolf and Frohberg, 2002) and a glass plate $0.10 \times 0.10 \times 0.002 \mathrm{~m}$ (Bauer et al., 2000), both located at $0.20 \mathrm{~m}$ in height from the ground. At the laboratory, labels were scanned and analyzed using the "CIR" software
(Conteo y tipification de impactos de pulverización) to characterize the droplet spectrum, evaluating VMD, RA and coverage. To Study spray mix deposition, a spectrophotometer analysis was performed, according to Palladini et al. (2005).

Drift quantification was performed by difference between actual volume applied and deposition volume calculated by means of deposition in each distance and its area of influence, according to Equation 1 and 2.

$A_{i}=\pi\left(D_{i}^{2}-D_{a}^{2}\right)$

(1)

$P_{t}=A_{i} \times C_{d} \times 0.01$

(2)

Where:

Ai-Área of influence, $\mathrm{m}^{2}$;

$\mathrm{Di}$ - Distance analyzed , $\mathrm{m}$;

$\mathrm{Da}$ - Previous distance analyzed, $\mathrm{m}$;

$\mathrm{Cd}$ - Deposition concentration, $\mu \mathrm{L} \mathrm{cm}{ }^{-2}$;

$\mathrm{Pt}$ - Total depositon, $\mathrm{L}$.

\section{Data analysis}

Data analysis consisted of a descriptive analysis, verification of spatial variability and Pearson correlation index between spray mix deposition and coverage. For descriptive analysis of data, kriging calculations, semivariograms creation and maps of spatial variability software GS + 7.0 (Gamma Design Software ${ }^{\circledR}$ ) was used. Hypothesis of normality of the data was verified by the Shapiro-Wilk test at $5 \%$ probability, and computer program Excel $2007^{\circledR}$. A total of 42 pairs of points were used to calculate the semivariogram with a minimum distance of $3 \mathrm{~m}$ and maximum of $20 \mathrm{~m}$. Analysis of spatial dependence was determined by the SDI, according to Zimback (2001). 


\section{Conclusion}

The results showed that the DMV of the droplets was 136 $\mu \mathrm{m}$. According to the application maps, there was a drift of $71.50 \%$ of the volume of the syrup applied. The geostatistical tool made the evaluation of the droplet spectrum and deposition possible by means of the preparation of the application maps. The proposed climatic recommendations for the application of agricultural pesticides do not apply to cost atomizers.

\section{Acknowledgments}

To Coordenation of Aperfeiçoamento de Pessoal de Ensino Superior (CAPES) for scholarship funding and financial aid.

\section{References}

Angelico JC (2006) Desempenho da cokrigagem na determinação da variabilidade de atributos do solo. Rev Bras Cienc Solo. 30:931-936.

Antuniassi UR, Baio FHR (2008) Tecnologia de aplicação de defensivos. In: Vargas L, Roman ES (eds). Manual de manejo e controle de plantas daninhas. 2nd ed. Embrapa Trigo. Passo Fundo, Brazil.

Baetens K, Ho QT, Nuyttens D, Schampheleire M, Endalew AM, Hertog MLATM, Nicolai $B$, Ramon $H$, Verboven $P$ (2009) A validated 2-D diffusion-advection model for prediction of drift from ground boom sprayers. Atmos Environ. 9: 1674-1682.

Balan MG, Abi-Saab OJG, Silva CG, Rio A (2008) Deposição da calda pulverizada por três pontas de pulverização sob diferentes condições meteorológicas. Semin-Cienc Agrar. 29: 293-298.

Bauer FC, Raetano CG (2000) Assistência de ar na deposição e perdas de produtos fitossanitários em pulverizações na cultura da soja. Sci Agric. 57: 271-276.

Boller W, Ferreira MC, Costa DI (2011) Condições do ar e angulação das folhas influenciam a qualidade das pulverizações na cultura da soja?. Rev Plant Dir. 121: 3337.

Cunha JPAR (2008) Simulação da deriva de agrotóxicos em diferentes condições de pulverização. Cienc agrotec. 32: 1616-1621.

Cunha JPAR, Bueno MR, Ferreira MC (2010) Espectro de gotas de pulverização com adjuvantes de uso agrícola. Planta Daninha. 28: 1153-1158.

Cunha JPAR, Peres TCM (2010) Influência de pontas de pulverização e adjuvante no controle químico da ferrugem asiática da soja. Acta Sci-Agron. 32: 597-602.

Cunha JPAR, Teixeira MM, Vieira RF, Fernandes HC (2008) Eficácia do fungicida clortalonil no controle de doenças do feijoeiro em função de bico de pulverização e de volume de calda. Rev Cienc Agrar. 31: 221-232.

Derksen RC, Zhu H, Fox RD, Brazee RD, Krause CR (2007) Coverage and drift produced by air induction and conventional hydraulic nozzles used for orchards applications. T ASABE. 50: 1493-1501.

Doble SJ, Matthews GA, Rutherford I, Southcombe ESE (1985) A system for classifying hydraulic nozzles and other atomizers into categories of spray quality. Br Crop Pr. 9: 112-122.
Duarte SJ (2015) Variabilidade espacial do solo em sistema plantio direto estabilizado. Dissertação de mestrado, Escola Superior de Agricultura Luiz de Queiroz, Piracicaba, Brazil.

Durigan JC, Correia NM (2008) Efeito de adjuvantes na aplicação e eficácia de herbicidas. In: Vargas L, Roman ES (eds). Manual de manejo e controle de plantas daninhas. 2nd ed. Embrapa Trigo. Passo Fundo, Brazil. Figueiredo F, Figueiredo A, Ramos A, Teles, P (2009) Estatística descritiva e probabilidades. In: Escolar (ed.). Problemas resolvidos e propostos com aplicações em R. 2nd ed. Lisboa, Portugal.Fritz BK, Hoffmann WC, Czaczyk Z, Bagley W, Kruger G, Henry R (2012) Measurement and classification methods using the ASAE S572.1 reference nozzles. J Plant Prot Res. 52: 447-457.

Gebler L (2011) Pontos de abastecimento de pulverizadores agrícolas: uma revisão comparando os modelos em uso. Rev Bras Eng Agr Amb. 15: 1180-1185.

Jamar L, Mostade O, Huyghebaert B, Pigeon O, Lateur M (2010) Comparative performance of recycling tunnel and conventional sprayers using standar and drift-mitigating nozzles in dwarf apple orchards. Crop Prot. 29:561-566.

Machado LO, Lana AMQ, Lana RMQ, Guimarães EC, Ferreira CV (2007) Variabilidade espacial de atributos químicos do solo em áreas sob sistema plantio convencional. Rev Bras Cienc Solo. 31: 591-599.

Minguela JV, Cunha JPAR (2010) Tratamento fitossanitário por via líquida: formação e transporte de gotas. In: Aprenda Fácil (ed.) Manual de aplicação de produtos fitossanitários. 1st ed. Viçosa, Brazil.

Paixão GP (2016) Caracterização de pulverizadores para aplicação de defensivos agrícolas na cultura do café. Dissertação de mestrado, Universidade Federal de Viçosa, Viçosa, Brazil.

Palladini LA, Raetano CG, Velini ED (2005) Choice of tracers for the evaluation of spray deposits. Sci Agric. 62: 440-445.

Quirino ALS, Teixeira MM, Fernandes HC, Ferreira LR (2013) Parâmetros da pulverização de defensivos agrícolas visando a redução da contaminação ambiental e do aplicador. Agrarian. 6: 161-166.

Reis EF, Queiroz DM, Cunha JPAR, Alves, SMF (2010) Qualidade da aplicação aérea líquida com uma aeronave agrícola experimental na cultura da soja (glycine max L.). Eng Agric. 30: 958-966.

Rodrigues GJ (2005) Critérios rastreáveis na aplicação de inseticida no controle do bicho mineiro do cafeeiro. Tese de doutorado, Universidade Federal de Viçosa, Viçosa, Brazil.

Rodrigues GJ, Teixeira MM, Alvarenga CB (2012) Desempenho operacional de pontas hidráulicas na determinação de parâmetros da pulverização hidropneumática. Biosci J. 28: 8-15.

Schneider JL, Oliveira GM, Balan RE, Canteri MG, Abi Saab OJG (2013) Cobertura de gotas de pulverização obtida com diferentes pontas e taxas de aplicação na parte aérea da cana-de-açúcar. Cienc Rural. 43: 797-802.

Silva Neto SP, Santos AC, Leite RLL, Dim VP, Neves Neto DN, Silva JEC (2012) Variação espacial do teor de matéria orgânica do solo e produção de gramínea em pastagens de capim-marandu. Biosci J. 28:41- 43.

Souza ZM, Marques Júnior J, Pereira GT (2009) Geoestatística e atributos do solo em áreas cultivadas com cana-de-açúcar. Cienc Rural, 40:48-56. 
Wolf RE, Frohberg DD (2002) Comparison of drift for four drift-reducing flat-fan nozzle types measured in a wind tunnel and evaluated using droplets can software. Paper presented at the 2002 ASAE Annual International Meeting / CIGR XV World Congress, Hyatt Regency Chicago, Chicago, Illinois, USA, 28-31 July, 2002.
Zimback CRL (2001) Análise espacial de atributos químicos de solos para fins de mapeamento da fertilidade do solo. Tese de doutorado, Universidade Estadual Paulista, Botucatu, Brazil. 